\title{
Covid-19 Pandemisinde Veteriner Hekimliği Etiği
}

\section{Veterinary Ethics in the Covid-19 Pandemic}

\section{Altan Armutak ${ }^{1}$ (D)}

\section{İstanbul Üniversitesi-Cerrahpașa, Veteriner Hekimliği Tarihi ve Deontoloji Anabilim Dalı, İstanbul,Türkiye}

ORCID: A.A. 0000-0003-0643-7492

Sorumlu Yazar/Corresponding Author: Altan Armutak,

İstanbul Üniversitesi-Cerrahpaşa, Veteriner Hekimliği Tarihi ve Deontoloji Anabilim Dal, İstanbul,Türkiye

E-posta: armutak@iuc.edu.tr

Başvuru/Submitted: 11.06.2021 Revizyon Talebi/Revision Requested: 10.08.2021 Son Revizyon/Last Revision Received: 13.08.2021

Kabul/Accepted: 29.08.2021

Online Yayın/Published Online: 28.10.2021

Atıf/Citation: Armutak A. Veterinary ethics in the Covid-19 pandemic. Sağlık Bilimlerinde İleri Araștırmalar Dergisi 2021; 4(Suppl.1): S63-S73. https://doi.org/10.26650/JARHS2021-950991
ÖZ

Amaç: Bu araştırma, yüzyılımızın pandemisi olarak tarihe geçen Covid-19'un yurdumuzda veteriner hekimliği etiği üzerine olan etkilerini ortaya koymak amacıyla gerçekleştirilmiş bir ilk çalışmadır.

Gereç ve Yöntem: Konuya yönelik sınırlı sayıdaki yerli ve yabancı kaynak incelenerek pandeminin boyutları ortaya konulmuştur. Bu çalışmalar araştırmamızın amacı doğrultusunda etik açıdan değerlendirilmiștir.

Bulgular: Salgının yurdumuzda ve dünyada hayvanlar, hayvan yakınları ve veteriner hekimler üzerine olan etkileri karşılaştırmalı olarak değerlendirilmiş ve diğer sağlık alanlarında olduğu gibi, veteriner hekimliğinde de birçok yönden ciddi etik sorunlara yol açtığı görülmüştür. Sonuç: Tüm bu bilgi ve yaklaşımların ışı̆̆ı altında Covid-19 ile ilgili yurdumuzda yeni çalışmalar yapılması ve yeni yaklaşımlar belirlenmesinin çok yararlı olacağı sonucuna varılmıştır. Anahtar Kelimeler: Covid-19 Pandemisi, Veteriner Hekimliği, Hayvan Hakları, Hayvan Refahı, Etik

\section{ABSTRACT}

Objective: This research is the first study carried out to reveal the effects of Covid-19, which went down in history as the pandemic of our century, on veterinary ethics in our country. Material and Methods: The dimensions of the pandemic were revealed by examining the limited number of domestic and foreign resources on the subject. These studies were evaluated ethically in accordance with the purpose of our research.

Results: The effects of the epidemic on animals, animal relatives and veterinarians in Turkey and in the world have been evaluated comparatively and it has been seen that it causes serious ethical problems in veterinary medicine as in other health fields.

Conclusion: In the light of all these information and approaches, it was concluded that it would be very useful to conduct new studies and determine new approaches regarding Covid-19 in Turkey.

Keywords: Covid-19 Pandemy, Veterinary Medicine, Animal Rights, Animal Welfare, Ethics 


\section{GİRIŞ}

Dünya Sağlık Örgütü, Çin'in Wuhan kentinde 2019 yılının Aralık ayının son günlerinde ortaya çıkan hastalığa Covid-19 adını verir ve bu daha sonra bu hastalığın bir pandemi olduğunu tüm dünyaya ilan eder. $\mathrm{Bu}$ virüs kısa sürede yaşamın olağan akışını etkileyerek tüm dünya çapında ciddi sorunlar üretir. Pandemi; gündelik yaşam, çalışma hayatı, eğitim-öğretim, bilim, kültür, sanat, siyaset, ekonomi ve uluslararası ilişkiler başta olmak üzere birçok alanda oluşturduğu problemler sonucu dünyada yepyeni bir dönem başlatır. Ayrıca turizm, ulaşım ve hizmet sektörü de pandeminin derin etkilerinden payını alır ve bir yandan da ekonomik kriz dünya çapında şiddetini arttırır. Covid-19'un çıkış nedeni aydınlatılamamış olsa da, hızlı yayılması ve özellikle ciddi can kayıplarına neden olması, salgının başlamasıyla birlikte aşı ve ilaç çalışmalarını çok hızlandırır. İnsanlık, belki de tarihinin en büyük savaşlarından birini vererek, salgın bir hastalığa karşı bilinçli bir varoluş mücadelesi sürdürmektedir $(1,2)$.

Covid-19 pandemisi en önemli etkilerinden bazılarını da sağlık bilimleri alanında hissettirmiştir. Sağlık Bilimlerinin en önemli dallarından biri olan veteriner hekimliği, bir yandan deontolojik ve etik yönden yeni problemlere sahne olurken; bir yandan da hayvan hakları ve hayvan refahı gibi alanlarda oluşan sorunların çözümü için yeni çıkışlar arama yoluna gitmiştir. Pandemi nedeniyle yüz yüze eğitim yerine, tercih edilmek zorunda kalınan çevrimiçi (online) eğitim sistemi, veteriner hekimliğin içine sürüklendiği sıkıntıları iyice artırmıştır.

Bu çalışmada, Covid-19 pandemisinin dünyada ve yurdumuzda veteriner hekimliği alanında oluşturduğu etik ve deontolojik problemler ortaya konulmaya çalışılmış ve “Tek Hekim-Tek Sağlık” başta olmak üzere olası çözüm yolları üzerinde durularak hayvan hakları ve hayvan refahı yönlerinden bu salgın, veteriner hekimliğin bakış açısı altında değerlendirilmiştir.

\section{GEREÇ VE YÖNTEM}

Covid-19 pandemisinin, yurdumuzda veteriner hekimliği üzerine olan etkilerini ortaya koyan her- hangi bir çalışmaya rastlanılmadığından, bu araştırma planlanarak gerçekleştirilmiştir. Bu makale, bu yönüyle de yurdumuzda veteriner hekimliği alanında bir ilktir. Bu araştırma için konuyla ilgili 2020 ve 2021 yıllarına ait yabancı makaleler taranarak incelenmiştir. Ayrıca, yurdumuzda Covid-19 pandemisine yönelik olarak veteriner hekimliği alanında yapılan mesleki uygulamaların ışığı altında etik, deontolojik, hayvan hakları ve hayvan refahı sorunları değerlendirilmiş ve çözüm yolları üzerinde durulmuştur. Çalışma 5 bölüm halinde düzenlenmiştir.

\section{BULGULAR}

\section{Covid-19 Pandemisinin Neden Olduğu De-} ontolojik Bir Sorun

Tarım ve Orman Bakanlığı, yurdumuzda pandeminin yayılmaya başladığı ve kapanma tedbirlerinin uygulanmaya başladığı 2020 yılı başlarında, bakanlığın resmi sayfasında Covid-19 tedbirleri kapsamında "Veteriner Hekimlerin Dikkat Etmeleri Gereken Hususlar" başlığı altında 22 maddelik alınması gereken biyogüvenlik tedbirlerini yayınlar (3). Yine Covid-19 pandemisinin tüm dünyada ve yurdumuzda etkili olmaya başladığ 1 ve daha hastalığın ciddiyeti ve büyüklüğünün anlaşılamadığı 2020 yılının başlarında Türk Veteriner Hekimleri Birliği Merkez Konseyi 30 Mart 2020 günü bu salgında veteriner hekimlere düşen görevleri belirten bir bildiri de yayınlar. Bildiride; korona ile mücadele kapsaminda, veteriner hekim oda başkanlıklarından acil koduyla, serbest veteriner hekim, klinik ve poliklinikleri ile hayvan hastanelerindeki solunum cihazı ve yoğun bakım üniteleri ekipmanların tam listesi istenir ve ihtiyaç duyulması halinde söz konusu tüm bu ekipmanların ve bilgi birikiminin insanlarımızın hizmetine sunulacağı dile getirilir. Daha sonra hastalığa karşı gerek birçok dünya ülkesinde gerekse ülkemizde aşı çalışmaları hız kazanır. Ülkemize ilk ithal aşılar 2020 yılının sonlarına doğru gelir. Ancak bununla birlikte, Covid-19 aşısı için öncelikli ve riskli olarak belirlenen meslek grupları içerisinde veteriner hekimlerin yer almadığı görülür (4).

Bunun üzerine Türk Veteriner Hekimler Birliği Merkez Konseyi Başkanlığı 2 Aralık 2020 günü şu 
açıklamayı yapar; "Bu aşı uygulamasında, yıllardır tek sağlık yaklaşımı kapsamında ve multidisipliner bir işbirliği içerisinde, başta zoonotik hastalıklar ve veteriner halk sağlığı olmak üzere beşeri hekimler ile birlikte mücadele eden veteriner hekimlerin yer almaması son derece üzücü ve düşündürücüdür”. Bu ifadeye ek olarak açıklamada, Covid-19 salgınının başladığı ilk günden itibaren veteriner hekimlerin hiçbir menfaat ve karşıllk beklemeksizin, sürece katkı ve katılımda bulunmak istediklerini ve bu durum ile ilgili birçok kez sözlü ve yazılı talep ve önerilerde bulunduklarını ancak, yeterli tecrübe ve birikime sahip veteriner hekimlerin yine de görmezden gelindiğine dikkat çekilir. Covid-19 ile laboratuvarlara kapanarak hayatları kurtaracak aşı ve serum üretmek için olağanüstü gayret gösteren başta veteriner hekim kökenli virolog akademisyenler olmak üzere ülke genelinde 35.000'e yaklaşan veteriner hekimin hayvan sağlığı ve refahı ile halk sağlığ ve gida güvenliği alanlarında en ücra yurt köşelerinde mesai gözetmeden görev yapıp hizmet vermeye devam ettikleri de israrla vurgulanir (4).

İşte bu hizmetler sırasında hayvanlara müdahale eden veteriner hekimler ile hayvan sahipleri arasında yakın temasın söz konusu olduğu, bu durumun da ciddi risk oluşturduğu ve bu noktadan hareketle gerek işletmelere gerekse evlere giden veteriner hekimlerden hem Covid-19'a yakalananların hem de yaşamını kaybedenlerin olduğu belirtilmiştir (4). Tüm bu açılamalar, veteriner hekimlerin aşı olmaları için ne kadar haklı gerekçelere sahip olduğunu ortaya koymak amacıyla yapılır.

Sonuçta, ülke genelinde Sağlık Bakanlığı bünyesinde yer alan tüm sağlık çalışanları 14 Ocak 2021 gününden başlayarak aşılanmaya başlanır ancak veteriner hekimler bu aşılamanın dışında tutulur. Veteriner hekimlerin diğer sağlık çalışanları gibi Sağlık Bakanlığı bünyesinde değil de Tarım ve Orman Bakanlığı bünyesinde hizmet vermeleri nedeniyle aş1lanmadıkları, dolaylı olarak da sağlık çalışanı sayılmadıkları görüşü önemli tartışmalara neden olur. Konu, yazılı ve sözlü basında gündeme gelir; ulusal kanalların çoğunda veteriner hekim oda başkanları tarafından bu sorun defalarca dile getirilir. Bu yak- laşımın yanlışlığına karşı, ciddi bir kamuoyu desteği sağlanır. Bir yandan da sorunu Türk Veteriner Hekimliği Merkez Konseyi’nin yanı sıra veteriner fakülteleri, veteriner hekim odaları, serbest çalışan veteriner hekimler ile Tarım ve Orman Bakanlığ 1 ile yerel yönetimlerde görev yapan veteriner hekimler de gündeme taşırlar. Sonuçta Sağlık Bakanlığı ile yapılan görüşmeler sonucu, Türk Veteriner Hekimleri Birliği Merkez Konseyi 20 Nisan 2021 günü itibariyle veteriner hekimlere Covid-19 aşısı uygulanacağını duyurur. Sağlık Bakanlığı bünyesindeki sağlık çalışanlarının aşılanmasından yaklaşık üç ay sonra, veteriner hekimlere de Covid-19 aşısı uygulanır (4). Buradaki problem yasal değildir. Bir yorum hatasına bağlı olabilir. Çünkü veteriner hekimler aşağıda belirtilen yasalar tarafından da sağlık çalışanı/personeli olarak kabul edilmiştir (5).

Veteriner hekimlerin görev ve yetkilerini içeren temel yasa; 6343 sayılı 18 Mart 1954 tarihli Resmi Gazete'de yayınlanarak yürürlüğe giren «Veteriner Hekimliği Mesleğinin İcrasına, Türk Veteriner Hekimleri Birliği İle Odaların Teşekkül Tarzına Ve Göreceği İşlere Dair Kanun«dur. Bu kanunun 1. Maddesi'nde Veteriner Fakülteleri mezunlarına "Veteriner Hekim" unvanı verildiği açı bir şekilde ifade edilmiştir. Ayrıca 5. Maddede; Veteriner hekimlerin vazife ve salahiyetleri aşağıda yazılı fikralarda gösterilmiştir: (5):

a) Hayvanları muayene, hayvan hastaliklarm tedavi etmek ve hayvanlar üzerinde muktedir olabildiği her türlü ameliyatı yapmak, ihtisası icab ettiren ahvalde ise mütehassis (Veteriner hekim) e müracaatı tavsiye eylemek;

b) Hayvanların vasıfları ve sağlık durumları hakkında rapor vermek;

c) Kara ve deniz hayvanlarından elde edilen gidai, sinai maddelerle mamullerini, hayvan yemi olarak kullanilan maddelerin muayene ve ihtisas sahibi ise tahlil etmek;

d) (Veteriner hekim) likte tatbik olunan her türlü aşı, serum, biyolojik maddelerle müstahzaratı (ihtisas sahibi olmak) ve bu maksatların tahakkuku için tedvin olunmuş hususi kanunların hükümlerine uymak şartıyla) ihzar, muayene, tahlil eylemek ve bu gibi husu- 
satta rapor verebilmek;

e) Eczanesi bulunmayan yerlerde hayvan hastaliklarında kullanılan her nevi aşı, serum, müstahzar ve biyolojik maddeleri muhtevi bir ecza dolabı tesis eylemek ve bu ilaçları satabilmek;

f) Memleket hayvancıliğının ıslah ve inkişafını engelleyici hareketleri ve bulaşıcı hayvan hastalıkların görür veya işitirse en kısa bir zamanda keyfiyetten resmi makamları haberdar etmek ve istilai mahiyet arzeden vakayide ise derhal muktedir olabileceği önleyici tedbirlere girişmek ve zootekni sahasında haiz olduğu ilmi salahiyetini kullanmak.

Görüldüğü gibi yukarıda belirtilen Yasa'nın 1. Madde'sinde veteriner hekim unvanı alan bu kişilerin 5. Madde'de görev ve yetkileri gösterilmiştir. Bu maddelerin hepsinde veteriner hekimlerin gerek hayvan sağlığının korunması ve gerekse hayvan hastalıklarının teşhis ve tedavisi başta olmak üzere halk sağlığ ve gıda güvenliği alanlarının da temel sağlık çalışanı olduğu açık ve net bir şekilde belirtilmiştir.

Bunun dışında 657 sayılı 'Devlet Memurları Kanunu'nun 36. Maddesi III. Bendinde veteriner hekimler sağlık personeli olarak yer alır: III - Sağlık Hizmetleri Ve Yardımcı Sağllk Hizmetleri Sınıfi:

"Bu sinıf, sağlık hizmetlerinde (Hayvan sağlı̆̆ı dahil) mesleki eğitim görerek yetişmiş olan tabip, diş tabibi, eczacı, veteriner hekim gibi memurlar ile bu hizmet sahasında çalışan yüksek öğrenim görmüş fizikoterapist, ttp teknoloğu, ebe, hemşire, sağlik memuru, sosyal hizmetler mütehassisı, biyolog, psikolog, diyetçi, sağlık mühendisi, sağlık fizikçisi, sağlık idarecisi ile ebe ve hemşire, hemşire yardımcısı, (Fizik tedavi, laboratuvar, eczacı, diş anestezi, röntgen teknisyenleri ve yardımcıları, çevre sağlığı ve toplum sağllğı teknisyeni dahil) sağllk savaş memuru, hayvan sağllk memuru ve benzeri sağllk personelini kapsar". (5):

Görüldüğü gibi veteriner hekimlerin sağlık personeli ya da sağlık çalışanı olduğu yasalar tarafından da şüpheye veya tartışmaya yer verilmeyecek kadar açık şekilde zaten ortaya konulmuştur. Ancak Sağlık Bakanlığı bünyesinde veteriner hekim kadrolarının bulunmayıșı ve bu mesleğin üyelerinin tamamen Tarım ve Orman Bakanlığı’na bağlı olarak çalışmaları yanlış bir yoruma neden olmuş olabilir. Sağlık çalı- şanlarının yalnızca Sağlık Bakanlığı’na bağlı olarak çalıştıkları düşünülerek, veteriner hekimlerin Tarım ve Orman Bakanlığı'na bağlı olarak hizmet vermelerine rağmen aslında sağlık çalışanı oldukları göz ardı edilmiștir. Görüldüğü gibi olayın hiçbir yasal dayanağı yoktur. Ancak böyle bir uygulama ile karşılaşılmış olunması, veteriner hekim camiasını ciddi şekilde rencide etmiştir. Bu uygulama kısa süre içerisinde bir deontolojik soruna dönüşmüş ve veteriner hekimliği mesleği üyeleri deontolojik bir savunu yapmak zorunda kalmışlardır.

\section{Covid-19 Pandemisine Karşı “Tek Tıp-Tek Sağlık" Kavramı}

Tek Tip kavramı, 1964 yılında hayvan ve insan sağlı̆̆ arasındaki karşılıklı ilişkiyi ve hayvanlarla insanlar arasında bulaşabilen zoonotik hastalıkları veya “zoonozları" önleme ve kontrol etmenin tıbbi gerçeklerini anlatabilmek için dünyaca ünlü epidemiyolog Prof. Dr. Calvin W. Schwabe'nin ortaya attığı bir kavramdır. Bu sayede tüm dünya zoonozların insanlar, gıda kaynakları ve ekonomileri için oluşturduğu risklerin farkına varır. Tek Tıp, tüm insan ve hayvan sağlı̆̆g ile ilgili hastalıklarının genel ifadesidir. İnsan ve hayvan sağlığında konu olan hastalıklar zoonozlardır. Bir diğer husus ise insan sağlığına yönelik olarak deney hayvanlarında yapılan bilimsel çalışmalar bu iki mesleğin “Tek Tip” ta birleştikleri ortak alandır. Tek Sağlık ise daha geniş bir sağlık ve hastalık anlayışı ile yalnızca insan, evcil hayvan ve yaban hayatı sağlığının birlikte ele alındığı uzlaşı ile elde edilebilecek bir yaklaşımdır. Çünkü böyle bir sağlık anlayı\$̧ı; insan, evcil hayvan ve yaban hayatı sağlığı ile hastalıklarının insanlara, gıda kaynaklarına ve ekonomilerine ve biyolojik çeşitliliğe yönelik tehdit olușturması arasındaki temel bağı kurar (6).

Adı tıp tarihine geçmiş Prof. Dr. Rudolf L. K Virchow (1821-1905) 1855 yllında ilk kez zoonosis terimini kullanarak insan ve hayvan enfeksiyonları arasında bağlantı kuran ilk bilim insanı olarak bu çalışmasıyla bilimsel ve tarihi gerçeği dile getirir ve "Ben sadece şunu bilirim ki; insan tıbbı ile veteriner tıbbı arasinda bir fark yoktur, olmamalıdır da, zaten bir alanda elde edilen deneyim diğer alanın gelişmesini destekleyecektir"şeklinde açıklamalarda bulunarak 
insan ve veteriner tıbbının işbirliğinin önemini vurgular. Daha sonra, modern tıbbın babası olarak bilinen Kanadalı Dr. William Osler (1849-1919), "Veteriner Hekimlik ve İnsan Hekimliği birbirini tamamlamaktadır ve tek tıp/tek hekimlik olarak düşünülmeli, kabul edilmelidir "şeklinde ki açıklamalarıyla hocası olan Virchow'u desteklemiştir Epidemiyolojinin babası olarak bilinen Prof. Dr. Calvin W.Schwabe, (1927-2006) 21. Yüzyılın en önemli zorluklarından olan "Zoonozlarla Mücadelede", tıbbın iki farklı disiplini olan "İnsan Tibbı" ile "Veteriner Tıbbı” nın işbirliğini önererek "Tek Tip, Tek Sağlık” çatısı altında toplanarak ortak hareket etmeleri halinde başarı elde edilebileceğini belirtmiştir (6).

Yarasaların, Covid-19'un etken maddesi olan SARS-CoV-2'nin hayvan kaynağ olduğuna dair güçlü kanıtlar olsa da, potansiyel hayvan yolları hakkında birçok belirsizliğin olduğunu ve bu pandeminin yönetilme şeklinin, Tek Sağlık anlayışıyla uyumlu olmayacak şekilde veteriner hekim katkısını küçümseme veya ihmal etme eğiliminde olduğunu ileri sürmektedirler (7). Tek Sağlık yaklaşımını daha işler hale getirmek için, veteriner hekimlik ve tıp hekimliği alanlarında ortaklaşa yürütülen müdahaleler çerçevesinde veteriner hekimliği mesleğinin Covid-19 pandemisini yönetmede çeşitli katkılar sağlayabileceğini belirtirler. Covid-19 pandemisinde bu duruma bağlı olarak veteriner hekimliği mesleğinin, güçlü bir Tek Sağlık vurgusu ile kendini ortaya koyup, konu ile ilgili tüm bilgi ve birikimini kullanarak ve yenilenmiş bir rolle, ulusal ve uluslararası düzeyde oluşturulan merkezi multidisipliner görev güçleri içine uygun bir şekilde entegre edilmesi gerektiğini vurgulayarak Tek Sağlık modelini savunurlar (7).

Covid-19 salgınının Kuzey Amerikalı veteriner hekimler için bir uyarı olduğunu ve veteriner hekimliğin, mevcut pandemiyi atlatmak ve gelecekteki pandemileri önlemek adına gerekli olan kamu hizmetlerini sunabilen paha biçilmez bir iş gücü olduğunu vurgularlar (8). Yine de Kuzey Amerikalı veteriner hekimlere, halk sağlığına katkılarını en üst düzeye çıkarabilecek çalışmalarda yeterince görev verilmediğini ileri sürerler. Veteriner hekimliğin yararlı hizmetleri hakkında yanlış yönlendirilmiş kamu algısı- nın Tek Sağlık oluşumunu engelleyebileceğini belirterek, genel olarak toplumda veteriner hekimliği mesleğinin evcil hayvanlardan kaynaklanan toplumsal yararları korurken daha fazla kamu hizmetine yönelik çaba göstermesini ve bunu çeşitlendirmesini talep ederler. Daha fazla sayıda veteriner hekimin çalışmalarında halk sağlığı temellerini benimsemesi durumunda küresel gıda güvenliğinin daha iyi korunabileceğini ve pandeminin değişim için bir firsat ve zorunluluk olduğunu; bu anı yakalayamamanın nesiller boyu halk sağlı̆̆ını ve küresel güvenliği baltalayabileceğini ileri sürerler (8).

Türk Veteriner Hekimliği Merkez Konseyi Başkanlığı “3 Kasım Dünya Tek Sağlık Günü”nde; insan, hayvan, bitki ve çevre sağlığına ilişkin bakış açısında acil bir dönüşüme ve daha bütüncül bir yaklaşıma ihtiyaç duyulduğunu belirterek, tıp doktorları, veteriner hekimler ve diğer sağlık personelinin bir arada çalışmasını sağlayacak ve oluşumun kurumsal alt yapısını da içeren bir “Tek Sağlık Yasası”nın çıkartılması ve bu yasaya bağlı olarak da uygun bir yapılanmanın oluşturulması gerektiği şeklinde bir çağrıda bulunmuştur (4).

Görüldüğü gibi gerek yurt dışındaki ve gerekse yurt içindeki mesleki ve akademik çevreler, Covid-19 Pandemisi ile mücadelede ve bir daha bu tip salgınların yaşanmaması adına “Tek Tıp-Tek Sağlık İlkesi” üzerinde durmuşlar ve pandemide veteriner hekimlerin yetki ve görevlerinin önemine değinmişlerdir. Bu ilke ile yeni pandemilerin yaşanmaması için, toplumlarda tıp ve veteriner hekimi başta olmak üzere tüm sağlık personelinin “Tek Tip-Tek Sağlık” çatısı altında toplanmaları günümüz koşullarında belki de tek çözümdür.

\section{Covid-19 Pandemisinin Veteriner Hekimli- ği Eğitim Süreci Üzerine Etkileri}

Covid-19 Pandemisinin ülkemizde görüldüğü ilk etapta yükseköğretime üç hafta süreyle ara verilmiş, 2020 Eğitim-Öğretim Yılı Bahar Yarıyılından sonra da tamamen çevrimiçi (online) eğitime geçilmiştir (9). Çevrimiçi eğitimin; hazırlıksızlık, fırsat eşitsizliği ve alt yapı yetersizliği gibi olumsuz yönlerine karşın; eğitimin devam etmesi, teknolojik okuryazarlık kazanılması ve alışılmadık bir deneyimin ya- 
şanması gibi olumlu yönleri de olduğu bildirilmiştir (10).

Covid-19 pandemisi sonrası alınan tedbirler ile sosyal mesafe sağlatılmaya çalışılmış ancak alınan önlemlerin mekânsızlaşma denilen yeni bir durumu ortaya çıkardığı, pandemi öncesi insan gücü eğitimde ve profesyonel iş hayatında bir mekâna bağlı iken, pandemi sürecinde mekândan uzak ve çevrimiçi platformlar üzerinden eğitim yapılabileceği görülmüştür. Açılan derslerin uygulama alanlarına bakıldığında sosyal bilimlerde $\% 91$, fen bilimlerinde $\% 78$, mühendislik bilimlerinde $\% 77$ ve sağlık bilimlerinde ise $\% 54$ olduğu görülmüştür (11).

İstanbuldaki üniversite öğrencilerinin çoğunun salgının ilk aşamasında yaşam koşullarında önemli değişiklikler olduğunu ortaya koymuş, birçoğu, Covid-19 önlemlerinin genel ekonomik etkileri nedeniyle mali zorluklar yaşamış; yerleşim yerlerinin kapatılması, aileden ayrı yaşamanın yük haline gelmesi ve hükümetin dönemin geri kalanını çevrimiçi derslerle devam ettirme kararı, öğrencilerin büyük çoğunluğunun daha yoğun nüfuslu olan aile evlerine geri dönmelerine neden olmuştur (12). Günlük rutinlerinin yerini büyük ölçüde bireysel ev aktiviteleri almış, sosyal etkileşimler büyük çoğunlukla dijital platformlara kaymıştır. Öğrencilerin ayrıca, Covid-19'un geniş bir yelpazeye sahip potansiyel olumsuz sonuçları ile ilgili önemli ölçüde yüksek düzeyde anksiyete ve sıkıntı yaşadıklarına dikkat çekmişlerdir (12).

Brezilya’nın Sao Paulo eyaletindeki tıp fakültesinde Covid-19 nedeniyle çevrimiçi eğitimin tıp öğrencilerinde kaygı, güvensizlik oluşturduğu ve iyi bir hekim olamama korkusu yarattığı; sosyal ilişkileri ortadan kaldırdığı, kampüs yaşamından uzaklaştırdığı ancak yine de bazı öğrencilerin hobiler edindikleri, bazı öğrencilerin de boş zamanları nedeniyle ruhsal ve bedensel sağlıklarını korumaya çalıştıkları bildirilmiştir (13).

Tüm dünyadaki yaklaşık 2 milyar öğrencinin 2020 yılı ilkbaharından başlamak üzere öğrenimlerinde alışılmış yüz yüze eğitimin yerini bir anda çevrimiçi yani online sistemin alması, bu kesimde, görüldüğü gibi ciddi bir uyum problemi oluşturmuştur. Öğretim elemanlarının da etkilendiği ve hazırlıksız yakalandıkları bu yeni uygulama, beraberinde getirdiği birçok probleme karşın öğrenime devam edilmesini zor da olsa sağlamıştır. Ancak sağlık bilimleri gibi usta-çırak yöntemiyle eğitim veren uygulamalı konvansiyonel bölümlerde, uzaktan, çevrimiçi uygulamanın olumsuz etkileri gelecekte çok daha kalıcı olabilir. Yukarıda verilen örneklerdeki sorunlar veteriner fakülteleri için de geçerlidir.

Diğer sağlık alanlarında olduğu gibi veteriner hekimliğinde de teknolojik alt yapı yetersizliği, bu teknolojinin etkin ve verimli şekilde kullanılamaması, öğrencinin uzun süre bilgisayar başında izole bir şekilde çalışması, öğrenci ile öğretim üyesi arasında sağlıklı bir diyalogun kurulamaması, öğrencinin fakültesinin ve üniversitesinin ona sunduğu sosyal ve kültürel olanaklardan yararlanamaması gibi durumlar sonuçta kendine güvensiz ve umutsuz öğrencilerin yetişmesine yol açabilir. Maddi ve psikolojik sorunlar, bu durumu daha da ağırlaştırır. Fakülteye yeni kayıt yaptıran öğrenciler, yüz yüze almaları gereken dersleri çevrimiçi/online almışlardır. Bu durum ve özellikle kampüs yaşamının etkinliğini yitirmesi, bu öğrencilerin üniversite yaşamına uyum sağlamakta zorlanmalarına neden olabilir. Kurum ve meslek kültürleri yetersiz kalabilir. Fakültenin daha üst sın1findakiler ve özellikle mezuniyeti yaklaşanlar kendilerine güvenlerini yitirerek yetersiz bilgi ve pratikle mezun olacaklarına inanabilirler. Bu durum öğrencilerin gelecekteki mesleki başarılarının olumsuz yönde etkileyebilir. Ayrıca, gerek yüksek lisans ve gerekse doktora derslerinin verilmesinde, gecikmeler ve problemler yaşanırken, özellikle derslerin, tez savunma ve doçentlik sınavlarının çevrimiçi yapılması uyum sorunları oluşturabilir. Tüm bunlara ek olarak Covid-19 pandemisi nedeniyle yaşanan sorunlar, deneysel ağırlıklı bilimsel araştırmalar yerine daha çok arşiv ağırlıklı istatistiksel çalışmaların artışına neden olabilir. Bu durum, bir süre sonra bilimsel araştırmalarda dejenerasyona yol açabilir ve niteliksiz çalışmaları üretebilir. 


\section{Covid-19 Pandemisinin Veteriner Hekimli- ği Etiği Üzerine Etkileri}

ABD'de veteriner hekimliği etiğini ilgilendiren konulara yönelik problemler, pandemi öncesinde ayda bir kaç kez görülürken pandemide haftada birkaç kez görülmeye başlanır. Bu etik sorun veya çatışmaların en önemlileri; müşterilerin mali durumları kısıtliyken nasıl hareket edileceğine dair zorlu kararlar, kişisel refah ve mesleki rol arasındaki çatışmalar, müşteriler ve hayvanlarının çıkarları arasındaki çatışmalar; neyin temel veterinerlik hizmeti olarak sayıldığına dair zorlu kararlar; aile üyelerinin esenliği ile mesleki rol arasındaki çatışmalar; temassız veteriner hekim ziyaretlerinin yapılıp yapılmayacağına dair zorlu kararlar ve işverenin çıkarları ile kendi çıkarları arasındaki çatışmalar şeklinde sıralanabilir (14). Görüldüğü gibi pandemi süreci, veteriner hekimliğinde etik sorunlarda da artışa neden olmuştur.

Uygulanan sokağa çıkma yasağı ve beraberindeki yalnızlık, özellikle Avrupa'da köpek ve kedilerin sahiplenilme sayısında artışa yol açmıştır. Bir evcil hayvana sahip olmak, sahibinin fiziksel ve zihinsel durumunu iyileştirir, ancak sahiplenen kişiye aynı zamanda daha büyük sorumlulukları da beraberinde getirir. Bir süre sonra hastalığın etkeni olan virüsün hayvanlardan insanlara bulaşması olasıllı̆g belirince bu durum, bir çok insanın sokak hayvanları da dahil olmak üzere evcil hayvanlarının çoğunu terk etmesine yol açar. Sonuçta, Hong Kong'dan ABD'ye kadar köpekler ve kediler kitleler halinde sokağa terkedilir. Karantinadan sonra insanların işlerine dönmeleri ve hayvan sahibi olurken sahip oldukları sorumlulukların oldukça yüksek olduğunun farkına varmaları da hayvanların terk edilmesine katkı sağlamıştır (15).

Dünya Sağlık Örgütü, kedi ve köpek gibi evcil hayvanların hastalığı bulaştırmada rol oynamadığı görüşünü savunmuştur. Örgüt ayrıca virüsün gıda tüketimi yoluyla da değil, damlacık yoluyla bulaşan bir solunum sistemi hastalığı oluşturduğunu hatırlatır. Yurdumuzda da 2020 yılındaki kapanma dönemlerinde evcil hayvan edinenlerin sayısı hızla artar. Bazı kişiler de bu hayvanları, sahiplerini pandemiden koruduklarına inandıklarından sahiplenirler. Ancak bir süre sonra bu hayvanların Covid-19 taşıdıklarına yönelik bir iddia gündeme gelince bu sefer de bu hayvanlar sokağa terk edilir. Türk Veteriner Hekimleri Birliği, yurdumuzda sokağa bırakılan evcil hayvan sayısının 20 kat arttığını, insana virüs bulaştırıyor iddiası nedeniyle çok sayıda evcil hayvanın bu dönemde sokağa atıldığını açıklar (4). Evde bakılan bir evcil hayvanın gerekçesi ne olursa olsun sokağa terkedilmesi, hayvan haklarına ve hayvan refahına aykırı bir tutumdur ve yasal değildir. Böylesi bir uygulamanın sonuçları, sokağa terk edilen hayvanların kısa bir süre içerisinde önce sağlıklarını daha sonra da yaşamlarını yitirmeleriyle sonuçlanacağından, hayvan sahiplenilirken bu hususa özellikle dikkat edilmesi gerekir.

Virüsü insanlara bulaştırdığından şüphelenilen Hollanda, İspanya ve Fransa'daki çiftliklerde de on binlerce kürk hayvanına ötenazi uygulanır. Ama en büyük eylem Danimarka’da gerçekleşir. Danimarka hükümetinin bir koronavirüs mutasyonunun rapor edildiğini açıklamasının ardından, insanlara bulaşabileceği veya aşılama eylemini tehlikeye atabileceği endişeleri nedeniyle, 17 milyon kadar vizon toplu halde öldürülür ve toplu mezarlara gömülür. Ülkenin başbakanı daha sonra insan mutasyonuna dair bir kanıt olmadığını söyler ve ülkede hasta bir vizon dahi olmadığını kabul eder (15). Görüldüğü gibi her salgın hastalık döneminde hayvanların toplu itlafları ya da ötenazileri gündeme gelmektedir. Geçmiş dönemdeki Kuş Gribi’nde olduğu gibi bu seferde Covid-19'dan haksız yere sorumlu tutulan milyonlarca hayvan dünyanın bazı ülkelerinde toplu şekilde öldürülür. Ancak böylesi insanlık dışı bir uygulamanın pandemi sürecinde ülkemizde uygulanması kesinlikle söz konusu olmamıştır.

Yeni Zelanda'daki karantina ya da kapanma sırasında hayvan yakınlarının çoğu evcil hayvanlarının sağlığının normalden daha iyi olduğunu düşünmektedir. Evde sürekli insanlarla yaşamaya başlayan bu hayvanlar karantina öncesine göre daha çok oyun oynarlar ve sürekli hareket halindedirler. Hayvan yakınları, karantina sonrası bu hayvanların sağlıklarından duydukları endişeyi dile getirirler. Ayrıca, karantina sonrasında oyun oynama oranlarında da 
artışa işaret ederler. İnsan-hayvan etkileşimi nedeniyle evcil hayvanlar, karantina sırasında daha yüksek bir refahtan yararlanabilirler. Ancak sahipleri tarafından bu hayvanların normal yaşama dönmeye hazırlanmaları gerektiği belirtilir. Kısacası, evcil hayvanların kapanma veya karantina dönemlerinde refahları daha yüksektir. Ancak normal yaşama geri dönüldügünde eğer ki bu hayvanlar sahipleri tarafından önceden hazırlanmazlarsa bu değișen koşullardan olumsuz yönde etkilenebilirler. Ayrıca İngiltere'de köpeklerin gezdirilme sıklığ 1 ve süresi azaldıkça diğer köpeklerle olan sosyal ilişkilerinin de bozulmaya başladığı dikkati çekmiştir. Ayrıca kapanma günlerinden sonra bu köpeklerin sahipleriyle daha yakın bir ilişki istediği, kısa süre bile yalnızlığa dayanamayarak sürekli ses çıkartma gibi belirtiler gösterdiği ya da havladığı izlenir (16). Kapanma veya karantina dönemlerinde, insanlarla sürekli bir arada yaşayan hayvanların refahları çok yükselse de, pandeminin kontrol altına alınmasından ve insanların tekrar işlerine ya da okullarına dönmelerinden sonra evde yalnız kalan bu hayvanların refahları içine düştükleri derin yalnızlık nedeniyle yeniden azalacaktır. Bu durum da doğal olarak hayvanları ruhsal veya bedensel bazı hastalıklara daha duyarlı hale getirebilir. İnsanlar ile kısa sürede bu kadar yakın yaşamaya alıştırılan hayvanların, pandemiden sonra sokağa terkedilmeleri, onlara çok daha büyük zararlar verebilecektir.

ABD’nde Covid-19 nedeniyle kesim işçilerinin çoğu hastalanınca, domuz mezbahalarında kesim çok azalır. Bu nedenle çiftliklerde kesim için bekleyen ve kesim ağırlı̆̆ına ulaşmış domuzlar mezbahaya gönderilemez. Bir süre çiftliklerde bekletilen 350.000 domuzun çoğu sonuçta ateşli silahlarla vurularak öldürülür. Binlerce hayvanı öldürmek zorunda kalmak insanlarda ruhsal sıkıntılara neden olabilir. Özellikle hayvan yetiştiricileri, hayvanları öldürmekten hoşlanmazlar ve bu işlemden çok etkilenirler. Bu durum ciddi etik problemlere ve hayvan hakları ile hayvan refahı ihlallerine yol açabilir. Bu durumun giderilmesi için domuz çiftliklerinde taşınabilir elektrikle bayıltma sistemleri ile kesimler yapılmaya başlanmıştır (17). ABD'nde hayvanların hemen hemen hepsinin bayıltılarak kesimlerinin yapıldığı dikkate alındığında, bu durum daha da iyi anlaşılabilir. Sadece pandemi dönemindeki olanaksızlıklar nedeniyle bu hayvanların bayıltılmadan ateşli silahlarla vurularak öldürülmeleri bile ABD'nde tepki toplamış ve tartışılmıştır. Hayvan refahının yüksek bir toplum olduğu ABD'ne karşın ülkemizde halen mezbahalardaki kesimlerin hepsinin kanlı/acılı klasik yöntemle yapılmaya devam edilmesi hayvan haklarına ve hayvan refahına aykırı olduğu gibi hiçbir etik anlayışla da izah edilemez.

Batı ülkelerinde Covid-19 sırasında evinde ölmüş, hastaneye kaldırılmıs veya tecrit ya da karantina altına alınmış kişilerin, evlerinde baktıkları ve yalnız kalmış hayvanlarının durumu da ayrı bir etik sorun olarak ortaya çıar. Bu durumdaki hayvanların saptanıp yaşadıkları evlerden alınmasında hayvan severlere ve veteriner hekimlere de görevler düşer (18). $\mathrm{Bu}$ durum ile ilgili ülkemizde hiçbir bildirim yoktur. Böyle durumlarda hasta ya da vefat etmiş yalnız kişilerin hayvanları evlerinde bakımsızlıktan hayatlarını kaybedebilecekleri gibi, sokağa salınmış ya da komşuları tarafından belediye veteriner işleri yetkililerine teslim edilmiş olabilirler.

İngiltere'de kapanma döneminde karantina ve sosyal mesafe uygulamaları, at sahiplerinin atlarını yönetme ve onlarla iletişim kurma becerilerinde değişikliğe yol açmıştır. At sahiplerinin çoğu atlarını daha az ziyaret etmiş ve daha az atlara binmişlerdir. Burada at sahipleri, atları ziyaret edip onlara binememekten ruh sağlıklarının ve mutluluklarının olumsuz yönde etkilendiğini bildirirler. $\mathrm{Bu}$ atlarla ilgili veteriner hekimlere de kısıtlı erişim olabileceğinden, at sahipleri bu dönemde, at sağlığı ve refahının da tehlikede olduğundan endişe ederler. At sahipleri ayrıca, pandemi nedeniyle oluşan mali sıkıntıların yine atların sağlığı ve refahını olumsuz yönde etkileyeceğini savunurlar (19).

Covid-19 kapanması sırasında öncelikli olarak yarış atlarını tedavi eden veteriner hekimler ve yarış at eğitmenleri telefon veya video konferans yoluyla görüşmüşlerdir. Bu iyi bir çalışma ilişkisi oluşturmuş, elektronik ortamdaki bu ortak çalışmada pandemi öncesine göre fazla bir değişiklik saptanmamıştır. Bu 
durum veteriner hekimlerce de olumlu karşılanmış ve telefon görüşmelerinin yanı sıra görüntüler veya videolar kullanılarak uzaktan daha fazla danışma hizmeti verilmiştir. Ancak, aralıklı bağlantı ve düşük kaliteli görüntüler ve videolar bu etkinliği zaman zaman sınırlamıştır (20). Yurdumuzda da Türkiye Jokey Kulübü’nün resmi sayfasında pandemideki kapanma uygulaması nedeniyle at yarışlarına ara verildiği ancak yarışların durdurulmasına rağmen atların bakım ve beslenme işlemlerinin kesintisiz devam ettiği bildirilmektedir. Burada söz konusu edilen işlemler içinde veteriner hekimliği hizmetleri de yer almaktadır (21).

\section{Covid-19 Pandemisine Yönelik Araştırma- larda Deney Hayvanı Kullanımı}

Korona’nın neden olduğu pandemi dünya çapında etkili olmaya devam ederken, bilim adamları Covid-19 hastalığını incelemek için uygun hayvan modellerini bulmak için yarıştılar (22). Covid-19 salgınının, aslında hayvan araştırmalarına ne kadar güvendiğimizi de açıça gösterdiğini; Covid-19'un birçok organ ve sistemi etkilediğini ve şu anda mevcut olan çeşitli alternatif yöntemlerin yetersiz kalarak tabloyu daha da karıştırdığını ve bu nedenlere bağlı olarak Covid-19 salgınında deney hayvanların kullanımının insan ve hayvan sağlığının geliştirilmesi için gerekli olduğu görüşü savunulmuştur. Covid-19 krizinin ancak aşı veya antiviral ilaç tedavisi ile aş1labileceği ve bunun için de araştırmalarda hayvan kullanımının vazgeçilmez olduğu, hayvan modelleri yoluyla alınacak sonuçların çok daha hızlı sonuç vereceği ileri sürülmüştür (23).

Bununla birlikte, bu aşırı kullanım aynı zamanda laboratuvar hayvanının bir araç gibi insanlar tarafından isteğe bağlı olarak kullanımına yol açmıştır. Bu deneysel çalışmalar bir kısmı Covid-19 pandemisinde hayvanlar kullanılmadan, mevcut teknoloji ile hayvanların yerini almaya yönelik çalışmalar ve girişimler de bulunmaktadır. Sonuç olarak; çeşitli eylemlerle kendini gösteren Covid-19 pandemisinde, insanlar ve hayvanlar arasındaki ilişkinin etiği, antroposentrik yani insan merkezlidir. Ancak hayvanların ahlaki statüsünün güçlendirilmesi ve insanlar ile hayvanlar arasındaki ilişkinin uzlaştırılması gere- kir. Bazen hayvanlara zarar vermenin ve kullanmanın kaçınılmazlığı durumunda hayata hürmet, eğitim ve mevzuat yoluyla hayvanların yaşam kalitesini arttırmak ihtiyacı doğabilir (15).

Antroposentrizmde, insanlar kendilerini doğada yaşayan diğer tüm canlılardan üstün sayarlar. İnsan olmayan doğa, insanın kullanımı için vardır. Bir başka deyişle insanların çevreye ya da o çevrede yaşayan diğer insan olmayan hayvanlara karşı herhangi bir etik sorumluluğu bulunmamaktadır. Bu yaklaşım özellikle deney hayvanlarının kullanımında akla gelen bir yaklaşımdır. Bu pandemide en büyük çekincelerden biri de görüldüğü gibi bu yöndedir. İnsanlar panik halinde Covid-19'a karşı aşı ya da ilaç geliştirmeye çalışırlarken, deney hayvanı etiğinin temel ilkelerine uymaya gereken özeni göstermeyebilirler. Covid-19 aşısı ve ilacı geliştirmek üzere yapılan projeler her geçen gün daha da artmaktadır ve daha da artabilir. Bu çalışmalarda kullanılan hayvanların sayıları da eğer etik ilkelere dikkat edilmezse gün geçtikçe yükselecektir. Ancak bu hayvanların refahları aynı oranda yükselmeyecek ve hatta refahları azalacaktır. Bu nedenle pandemiyi konu edinen ve canlı deney hayvanlarının kullanılacağı araştırmalara yönelik hayvan deneyleri etik kurullarının çok daha dikkatli ve özenli olmaları ve deney hayvanları etiği ile hayvan hakları ve hayvan refahı ilkelerinden taviz vermemeleri gerekir. Panik halinde Covid-19 için aşı ya da ilaç geliştirileceğini iddia eden her projeye ihtiyatla yaklaşılmalı ve masum deney hayvanlarının feda edilmelerine değmeyecek çalışmalara etik yönden izin verilmemelidir.

\section{TARTIŞMA}

Dünyada yaklaşık 2 yıla yakın süredir etkili olan Covid-19 pandemisi birçok alanda olduğu gibi veteriner hekimliğinde de etkili olmuştur. Pandemi etkilerini; deontolojik ve etik sorunlarla, hayvan hakları ve hayvan refahı ihlalleriyle ve veteriner hekimliği eğitim-öğretiminde çevrimiçi/online sisteme bağlı olarak meydana gelen ve etkileri daha sonra şekillenecek problemlerle ortaya koymaktadır. Bu tip pandemilerin bir daha yaşanmaması adına Tek Tıp-Tek Sağlık yönteminin benimsenmesinin tek çözüm ola- 
cağı ileri sürülmektedir. Bu çalışma yurdumuzda veteriner hekimliği mesleğine Covid-19'un etkilerini araştıran ilk makaledir. Öncü olarak kabul edilebilecek bu makalenin yanı sıra, gelecekte planlanacak ve veteriner fakültesi öğretim üyeleri, öğrencileri, serbest/ klinik veteriner hekimler, bakanlık ya da belediyelerde görev yapan veteriner hekimler ile hayvan yakınlarının katılacakları anket çalışmaları başta olmak üzere birçok yeni araştırmayla, Covid-19 pandemisinin veteriner hekimliğimize olan etkilerinin daha sağlıklı ve daha detaylı olarak değerlendirilebileceği kanaatindeyiz.

Hakem Değerlendirmesi: Dış bağımsız.

Peer Review: Externally peer-reviewed.

Çıkar Çatışması: Yazar çıkar çatışması beyan etmemiștir.

Conflict of Interest: Author declared no conflict of interest.

Finansal Destek: Yazar finansal destek beyan etmemiştir.

Financial Disclosure: Author declared no financial support.

\section{KAYNAKLAR}

1. Arslan İ, Karagül S. Küresel Bir Tehdit (COVID-19 Salgını) ve Değişime Yolculuk. Üsküdar Üniversitesi Sosyal Bilimler Dergisi, 2020;10:1-36.

2. Yücel E. 50 Maddede Salgınlar. Karakarga Yayınları, İstanbul 2020.s.241-62.

3. Tarım ve Orman Bakanlığı Resmi Sayfası. Covid 19 Tedbirleri. Veteriner Hekimlerin Dikkat Etmeleri Gereken Hususlar. 2020, Available from: https://www.tarimorman.gov.tr

4. Türk Veteriner Hekimleri Birliği (TVHB) Ana Sayfa-Basın Arşivi. 2020-2021 Available from: tvhb.org.tr/basin-arsivi/

5. T.C. Cumhurbaşkanlığı Mevzuat Bilgi Sistemi 2020 https://www.mevzuat.gov.tr/mevzuat?Me vzuatNo $=6343 \&$ MevzuatTur $=1 \&$ MevzuatTert ip=3 \& "https://www.mevzuat.gov.tr/mevzuat? MevzuatNo $=657 \&$ MevzuatTur $=1 \&$ MevzuatTert $\mathrm{ip}=5$

6. Serpen A. Tek Sağlık: Türk Tabipler Birliği Covid-19 Pandemisi Altınc1 Ay Değerlendirme Raporu 2020.s.683-99.
7. Ferri M, Evans ML. The contribution of veterinary public health to the management of the COVID-19 pandemic from a One Health perspective. One Health 2021;12:100230 doi: 10.1016/j.onehlt.2021.100230

8. Fathke RL, Rao S, Salman M. The COVID-19 Pandemic: A time for veterinary leadership in one health. One Health 2021;11:100193 doi: 10.1016/j.onehlt.2020.100193

9. Yükseköğretim Kurumu. Basın Açıklaması: 26.03.2020; Available from: https:// www.yok.gov.tr/Sayfalar/Haberler/2020/ YKS\%20Ertelenmesi\%20Bas\%C4\%B1n\%20 A\%C3\%A7\%C4\%B1klamas\%C4\%B1.aspx

10. Altınpulluk H. Türkiyedeki Öğretim Üyelerinin Covid-19 Küresel Salgin Sürecindeki Uzaktan Eğitim Uygulamalarına İlişkin Görüşlerinin İncelenmesi. Gazi Üniversitesi Gazi Eğitim Fakültesi Dergisi 2021;41(1):53-89.

11. Dikmen S, Bahçeci F. Covid-19 Pandemisi Sürecinde Yükseköğretim Kurumlarının Uzaktan Eğitime Yönelik Stratejileri: Fırat Üniversitesi Örneği. Turkish Journal of Educational Studies 2020;7(2):78-98.

12. Yorguner N, Bulut NS, Akvardar Y. COVID-19 Salgını Sırasında Üniversite Öğrencilerinin Karşılaştığı Psikososyal Zorlukların ve Hastalığa Yönelik Bilgi, Tutum ve Davranışlarının İncelenmesi. Arch Neuropsychitry 2020;58(1):310.

13. Chinelatto LA, Da Costa RT, Mederios VMB, Boog GHP, Hojaij FC, Tempski PZ, et al. What You Gain and What You Lose in Covid-19: Perception of Medical Students and Their Education. Clinics (Sao Paulo) 2020;75:e2133. doi.org/10.6061/clinics/2020/e2133

14. Quain A, Mullan S, McGreevy PD, Ward MP. Frequency, Stressfulness and Type of Ethically Challenging Situations Encountered by Veterinary Team Members During the COVID-19 Pandemi Front Vet Sci 2021;8:647108. doi: $10.3389 /$ fvets.2021.647108. eCollection 2021.

15. Coman C, Ancuta D. Ethics Of the HumanAnimal Relationship in the COVID-19 Pandemic. JIME 2021;4(1):67-75. 
16. Esam F, Forrest R, Waran N. Locking down the Impact of New Zealand's COVID-19 Alert Level Changes on Pets. Animals (Basel) 2021;11(3):758.

17. Grandin T. Methods to Prevent Future Severe Animal Welfare Problems Caused by COVID-19 in the Pork Industry. Animals (Basel) 2021;11(3):830.

18. Adamelli S, Tocchio A, Brini, C. COVID-19 Pandemic and Rescue of Pets. The Role of Veterinarians in the Human-AnimalEnvironment Relationship at the Time of the Coronavirus. Journal of Applied Animal Ethics Research 2020;3(1):91-102.

19. Williams JM, Randle H, Martin D. Covid-19: Impact on United Kingdom horse owners. Animals (Basel) 2020;10(10):1862.
20. Butler D, Upton L, Mullan S. Capturing beneficial changes to racehorse veterinary care implemented during the Covid-19 Pandemic. Animals (Basel) 2021;11(5):1251.

21. Türkiye Jokey Klübü (TJK), At Yarışlarına ara verildi. 18.03.2020. Available from:URL:https:// www.tjk.org

22. Lakdawala SS, Menachery VD. The Search for a Covid-19 Animal Model. Science 2020;368(6494):942-3.

23. Genzel L, Adan R, Berns A, Van den Beucken JJ. How the Covid-19 pandemic highlights the neccesity of animal research. Curr Biol 2020;30(18):R1014-R1018. 
